\title{
Soviet Timber: Regional Supply and Demand, 1970-1990
}

\author{
BRENTON M. BARR ${ }^{1}$
}

\begin{abstract}
This paper investigates a specific problem, namely the ability of Soviet regional timber resources, particularly those of Northern European Russia and Siberia, to sustain the demands expected to be placed on them by world and domestic markets in 1990 , the final year of the fifteen-year intermediate-future planning or forecasting period now guiding much of the national and spatial development of the Soviet economy. Contrary to the findings of other studies, this analysis suggests that the Soviet forest resource has sufficient potential to satisfy all planned domestic requirements and a large share of foreign demand in 1990, and in the years immediately following that date, if technological improvements in the comprehensive use of roundwood continue to be made in the Soviet wood-processing industry. When expected 1990 Soviet timber exports are compared to the United Nation's estimate of world demand for Soviet timber in the year 2000, the USSR appears able to fulfill but not to overwhelm most potential world demand for its timber although world markets will likely continue to secure a significant portion of their coniferous timber needs from North American, especially Canadian, forests.
\end{abstract}

RESUMÉ. Cet article analyse un problème particulier, celui de la capacité des Sovietiques en ressources locales de bois de charpente, en particulier en Russie d'Europe du Nord et en Siberie, pouvant repondre à la demande mondiale et à leurs propres besoins en 1990, dernière année d'un plan à quinze ans, à moyen terme et d'une pèriode de previsions interessant une bonne partie du developpement de l'économie Sovietique.

Contrairement aux idées géneralement admises, cette analyse suggère que les ressources forestières Sovietiques ont un potentiel suffisant pour satisfaire à tous les besoins interieurs prévisibles à une bonne partie de la demande étrangère en 1990 et dans les années immediatement à venir, si l'industrie Sovietique du bois continue à réaliser des améliorations technologiques dans l'utilisation à bon escient du bois en rondin. La comparaison des exportations Soviétiques previsibles, en bois de charpente avec l'estimation des "Nations Unies," de la demande mondiale en bois de charpente Sovietique en l'an 2000, permet de pense que l'U.R.S.S. parait capable de faire face, mais pas beaucoup plus, à une grande partie de la demande mondiale en bois de charpente alors que les marchés mondiaux continueront vraisemblablement à garantir une partie significative de leurs besoins en bois de conifère, à partir des forets nord Américaines et specialement du Canada. Traduit par Alain de Vendegies, Aquitaine Co. of Canada Ltd.

\section{INTRODUCTION}

\section{Purpose}

The timber and wood-processing industries are analyzed here for 1970 , 1975, and 1990. The first date, representing the beginning of a decade in which the Soviet Union participated heavily in international markets, symbolizes the structure of the Soviet wood-processing and timber industries in the years prior to detente, the much-publicized expansion of commercial relations between the USSR and the Industrial West. The year 1975 represents the final year of the Soviet Ninth Five Year Plan, and a benchmark year for evaluating

'Professor of Geography, The University of Calgary 
the orientation and expected performance of the still-unpublished, but much publicized, Fifteen Year Plan, 1976-1990.

The year 1990, is the final year of a period in which the Soviet Union is expected to fulfill a comprehensive set of economic objectives which have attendant geographical implications for regional development and international commodity sales. Although a draft of the Fifteen Year Plan was rejected by Gosplan USSR in 1977, its basic propositions were retained in the working document now described as the "General Outline for the Location of Productive Forces in the USSR for the Period Ending 1990" (Shabad, 1977b), and the year 1990 still represents the final year of a period in the intermediate-term future for which a scenario of regional resource extraction and consumption can be acceptably derived now. In view of the apparent conflicts in future objectives existing within Soviet economic planning agencies, the 1990 scenario of timber production and markets presented here seems to be a reasonable basis on which to estimate the geography of these phenomena which will occur if Soviet planners and administrators continue to act in a manner which is at least consistent with that of the past two decades. The scenario for 1990 is not an economic forecast; it is a portrayal of a possible future regional productive structure of the Soviet timber and wood-processing industries, and the significance these industries may have for other industrial nations of the world. The scenario will be deemed to have utility if it elicits criticism in the prognostications of related research on the USSR.

Analysis of the Soviet timber and wood-processing industries for 1970, 1975, and 1990 reported here and in Barr (1978) also provides an appropriate sequel to previous work on these industries for the years 1956, 1960, and 1964 by the author (Barr, 1970, 1971).

\section{Objectives of the Supporting Research Project}

A comprehensive investigation (Barr, 1978) has evaluated the spatial relationship between the regional availability of Soviety industrial roundwood (timber) and the regional and international location of timber consumption; it determined the influence of foreign and domestic demand for industrial roundwood (or its equivalent) in $\mathbf{1 9 9 0}$ on the regional supply of Soviet timber, estimated demand by each type of consumer for roundwood in eighty-seven Soviet regions, derived optimal roundwood flows to satisfy regional timber demand, and assessed optimal regional "costs" and "prices" associated with the location of domestic timber supply and demand. Satisfaction of these objectives enabled statements to be made here concerning the ability of the USSR to sell significant quantities of timber on international markets by 1990 , and to satisfy domestic and international demand for timber from specific regions (Figures 1 and 2).

\section{Related Literature}

Soviet sources underlie and support all of the topics covered in the present paper, although the method of analysis and arrangement of data in this study differ noticeably from those in Soviet reports (Barr, 1966). 


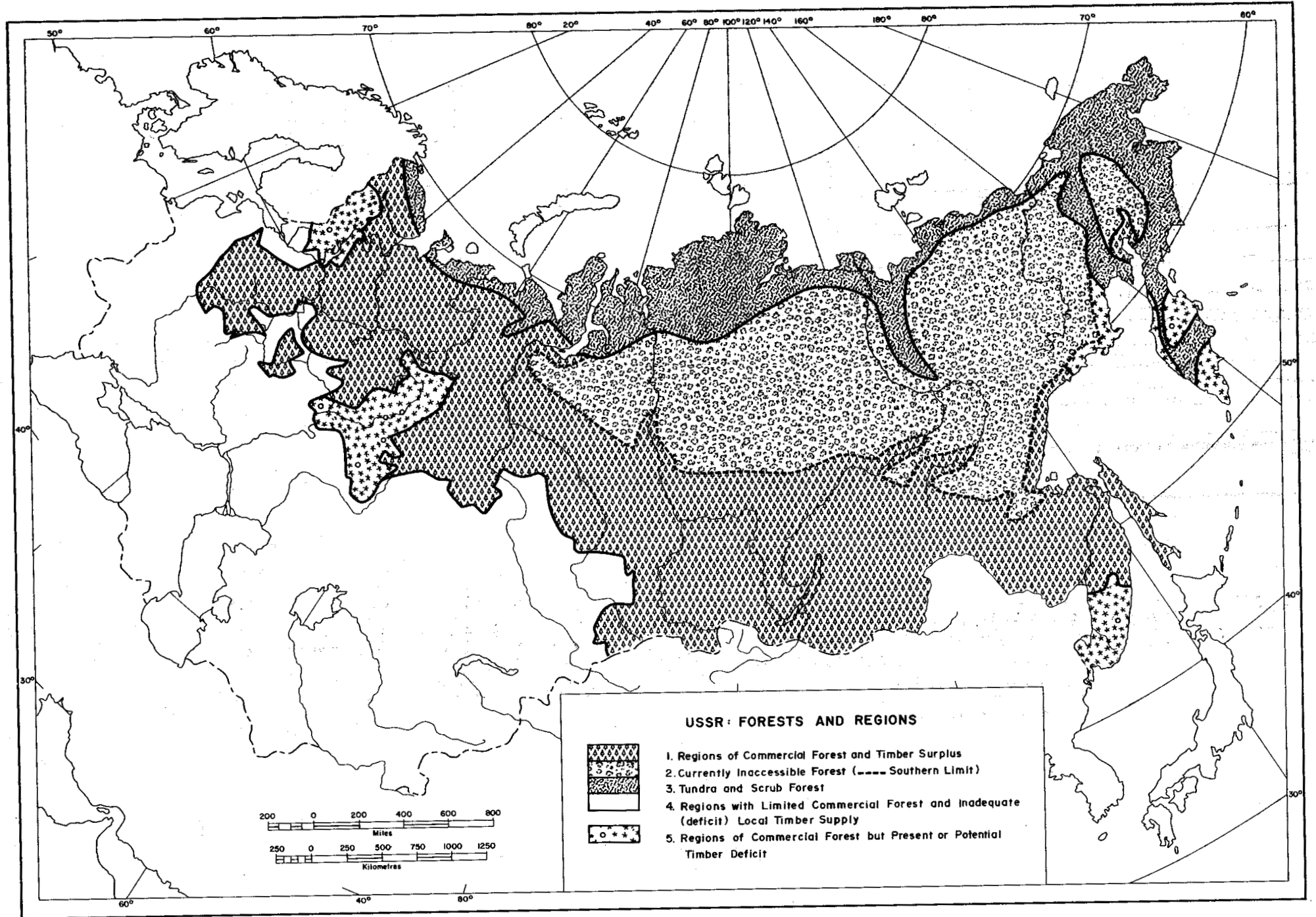




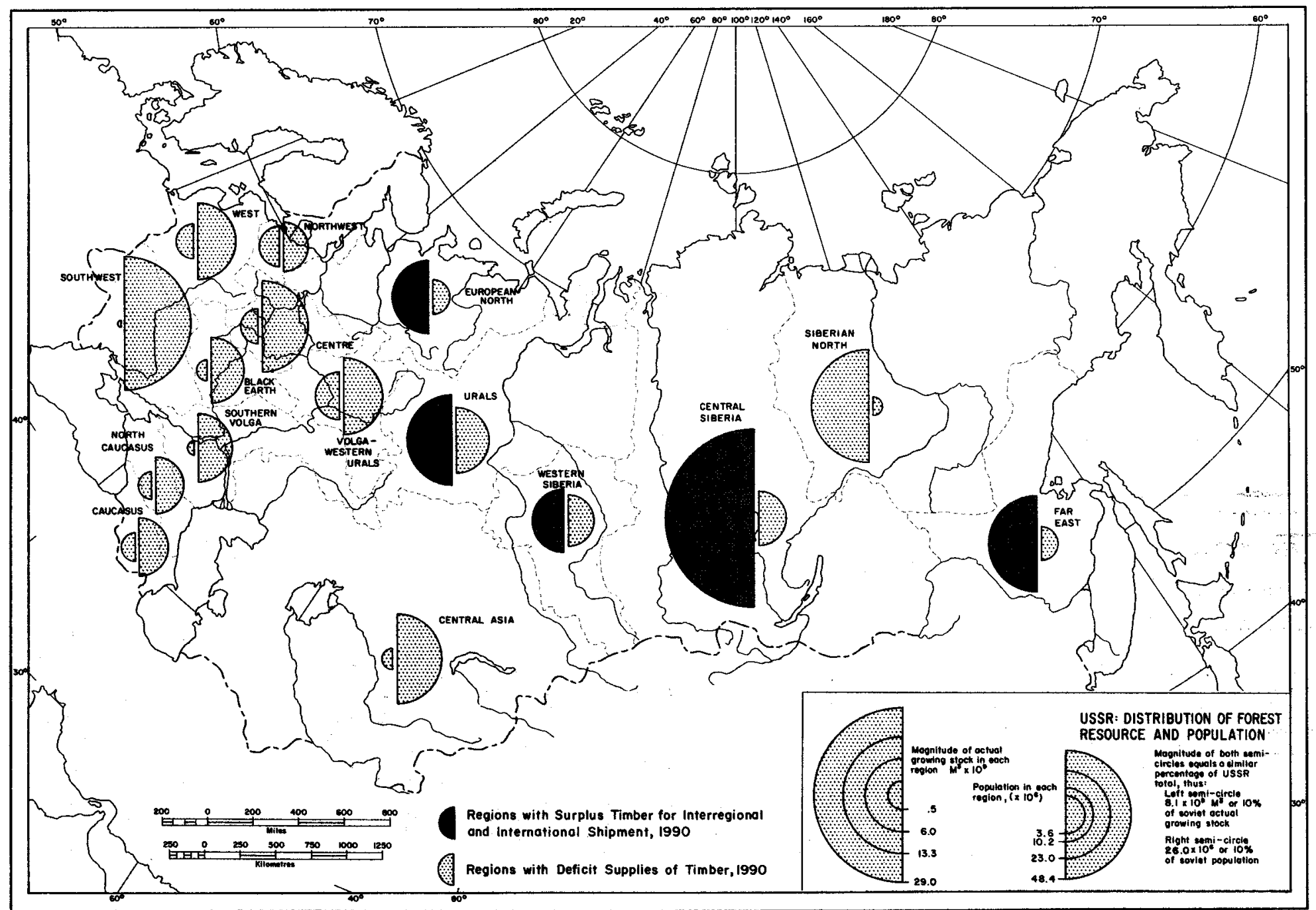

空

F IGURE 2 
Few studies are specifically related to geography and those which do emphasize regional variation generally rely on a typology of regional units consisting of the fourteen non-Russian republics and the ten major economic regions of the RSFSR. Soviet publications offer on the one hand a plethora of observations, projections and general comments, and on the other hand, force the non-Soviet observer to piece together data from many diverse sources, including statistical handbooks and research monographs.

Previous studies by the author, for example, emphasize the spatial variation in timber and wood processing and the general problem of the efficient allocation of regional surpluses to deficit areas within the USSR. Sutton (1973) and North and Solecki (1977) review the general operational characteristics of timber supply, industrial production, and trade, and from numerous published evaluations of specific aspects of the forestry industry seek a consensus estimation of the USSR's ability to achieve significant increases in foreign sales of wood and wood products. Sutton concludes that "the optimism of many overseas commentators on the size of the USSR forest resource and its ability to boost future world supplies is not supported by a detailed analysis of the resource or the current plans for its utilization (Sutton, 1975, p. 136). North and Solecki suggest that the Soviet Union has the potential to increase supplies of timber to domestic and international consumers and that "forest products offer one of the best long-term potentials for foreign earnings" but caution that many competing economic and policy considerations mean that "substantial growth in the Soviet Union's forest product exports to western countries seems, at the very least, unlikely in the foreseeable future" (North and Solecki, 1977, pp. 310-11).

Empirical evidence presented in the present paper, however, strongly supports the contention that the Soviet Union has the ability to achieve significant increases in the production of timber and wood products by 1990 if the annual increment of production in each industry is similar to that achieved between 1964 and 1975. Furthermore, the expected 1990 harvest of industrial roundwood and household fuelwood is only 96 percent of the "most realistic" estimate of the USSR's annual allowable cut reported in Sutton (1975, p. 112). The expected 1990 harvest, however, represents a still smaller proportion (72.4 percent) of the USSR's allowable annual cut recently estimated by the Canadian forester, J. H. Holowacz, but rejected by Sutton (1975, p. 112).

Soviet plans for railway construction alone seem to indicate that sufficient new timber supplies will be accessible via combined water and rail transport to support the scenario of wood processing for 1990 presented in this paper. Thus, although the forecasts of future wood shortages by other analysts appear intuitively correct for some unspecified future date, careful assessment of the incremental supply and demand in the timber and wood-processing industry since 1964 leaves little doubt that the Soviet Union will be able to play a significant role on international markets throughout the rest of the twentieth century if it continues to expand its forest industries in the same modest manner as that recorded for 1964-1975, or 1970-1975. 
A recent United Nations review (1976) fills an important need in the present study by estimating the potential demand for forest products in Europe for the rest of this century and the possible role which North America and the USSR might play in satisfying future world and European timber demands because "they increasingly affect the supply of forest products to Europe" (United Nations, 1976, p.i.) If the predictions of demand in Europe and Japan, the major foreign destinations of Soviet timber, are accepted as valid, then the possible role accorded to Soviet timber supply can be integrated with the present study's estimates of the regional values of Soviet timber available for international sale by 1990 .

\section{Data}

Problems related to Soviet forest statistics discussed previously by the author (Barr, 1970, 1971, 1972) have not abated in the interim (this topic is reviewed at length in Barr, 1978). Furthermore, occasional statistical handbooks of the 1960 s specifically related to Soviet industry have never been included among the publications of official data in the 1970s. Despite the greater general volume of Soviet literature now associated with the forest industry, the availability of "hard" data has declined and the relevant forestry sections of the two most important annual general statistical handbooks, Narodnoye Khozyaystvo SSSR and Narodnoye Khozyaystvo RSFSR, have diminished in size. These two publications, however, remain the most important source of information on the physical volume of regional production by the timber and wood-processing industries.

The handbook Narodnoye Khozyaystvo SSSR (1977), a jubilee edition celebrating sixty years of Soviet rule, contains figures for the production of timber, lumber, and paper by union republic; no other products are listed by union republic, and no data at all are available for the output of timber or wood products by large economic region or by oblast.

The 1977 issue of Narodnoye Khozyaystvo RSFSR (1977), also a jubilee volume, provides production figures only for lumber, plywood, paper and paperboard in provinces of the Russian republic - the most important major area for forest-based industries in the USSR. Comprehensive regional analysis of the timber and wood-processing industries, however, requires additional data on the output of commercial timber, roundwood substitutes, chemical and mechanical pulp, matches, particleboard, fiberboard, timber for export, and those items consumed in unprocessed form which constitute one-quarter of the Soviet demand for timber. Regional production of these items must be estimated from fugitive data, i.e., from data appearing incidentally in other sources, or from specific studies of individual industries or regions.

Soviet foreign trade data are published annually and although some items have been reported missing from recent volumes (Shabad, 1977a), data pertaining to timber are adequate for this study although the regional origin of export-destined timber is not published in official statistical compilations.

This study utilizes data on the regional origin of exported timber published by Kanevskiy and Shaytanov (1975) for the year 1972. The total amount of 
TABLE 1. USSR Timber Supply and Demand

\begin{tabular}{|c|c|c|c|c|c|c|}
\hline Item & $\begin{array}{l}1970 \text { Volume } \\
\text { (Roundwood } \\
\text { Equivalent: } \\
\left.M^{3}(\mathrm{r}) \times 10^{3}\right) \\
\end{array}$ & $\begin{array}{l}\% \text { of } \\
\text { Total }\end{array}$ & $\begin{array}{l}1975 \text { Volume } \\
\text { (Roundwood } \\
\text { Equivalent: } \\
\left.M^{3}(r) \times 10^{3}\right) \\
\end{array}$ & $\begin{array}{l}\% \text { of } \\
\text { Total }\end{array}$ & $\begin{array}{l}1990 \text { Volume } \\
\text { (Roundwood } \\
\text { Equivalent: } \\
\left.M^{3}(\mathrm{r}) \times 10^{3}\right) \\
\end{array}$ & $\begin{array}{l}\% \text { of } \\
\text { Total }\end{array}$ \\
\hline \multicolumn{7}{|l|}{ Supply } \\
\hline Commercial Roundwood & $298,548.00$ & 93.1 & $312,902.00$ & 89.7 & $355,964.00$ & 82.1 \\
\hline Industrial Fuelwood & $12,600.00$ & 3.9 & $22,200.00$ & 6.4 & $51,000.00$ & 11.8 \\
\hline Wood Chips and Mill Waste & 9.000 .00 & 2.8 & $13,300.00$ & 3.8 & $26,200.00$ & 6.0 \\
\hline Imported Roundwood & 468.30 & .2 & 286.17 & .1 & 286.17 & \\
\hline \multirow{2}{*}{\multicolumn{7}{|c|}{ Total Supply for Domestic }} \\
\hline & & & & & & \\
\hline Consumption & $305,316.30$ & 95.2 & $331,819.17$ & 95.1 & $411,327.78$ & 94.9 \\
\hline Lumber & 176.636 .46 & 55.1 & $176,346.94$ & 50.6 & $175,478.38$ & 40.5 \\
\hline Plywood & $6,462.20$ & 2.0 & $6,950.10$ & 2.0 & $8,413.80$ & 1.9 \\
\hline Chemical Pulp & $25,036.55$ & 7.8 & $33,516.00$ & 9.6 & $58,954.35$ & 13.6 \\
\hline Groundwood Pulp & $4,011.75$ & 1.3 & $4,206.00$ & 1.2 & $4,788.75$ & 1.1 \\
\hline Sleepers & $9,623.53$ & 3.0 & $9,741.18$ & 2.8 & $10,094.13$ & 2.3 \\
\hline Matches & 936.17 & .3 & $1,104.93$ & .3 & $1,611.21$ & \\
\hline Fiberboard & 395.77 & .1 & 779.00 & .2 & $1,928.69$ & \\
\hline Particleboard & $2,592.72$ & .8 & $5,144.10$ & 1.5 & $12,798.24$ & 3.0 \\
\hline \multicolumn{7}{|l|}{ Subtotal: Major Wood-processing } \\
\hline Industries & $225,695.15$ & 70.4 & $237,788.25$ & 68.2 & $274,067.55$ & 63.2 \\
\hline Tanning-Extractive Material & 900.00 & .3 & $1,012.50$ & .3 & $1,350.00$ & .3 \\
\hline Material for Processing Acetic Acid & 800.00 & .3 & 800.00 & .2 & 800.00 & \\
\hline Packing Wood & $8,000.00$ & 2.5 & $9,142.88$ & 2.6 & $12,571.52$ & 2.9 \\
\hline Pit Props & $18,000.00$ & 5.6 & $14,300.00$ & 4.1 & $3,200.00$ & \\
\hline Poles & $5,600.00$ & 1.7 & $6,272.00$ & 1.8 & $8,280.00$ & 1.9 \\
\hline Ship and Marine Timber & $2,400.00$ & .7 & $2,400.00$ & .7 & $2,400.00$ & \\
\hline \multicolumn{7}{|l|}{ Construction and Miscellaneous } \\
\hline Timber & $43,921.15$ & 13.7 & $60,103.54$ & 17.2 & $108,650.71$ & 25.1 \\
\hline Subtotal: Other Uses & $79,621.15$ & 24.8 & $94,030.92$ & 26.9 & $137,260.23$ & 31.7 \\
\hline Roundwood Export & $15,300.00$ & 4.8 & $16,869.00$ & 4.9 & $22,122.39$ & 5.1 \\
\hline Total Demand & & 100.0 & $348,688.17$ & 100.0 & $433,450.17$ & 100.0 \\
\hline Total Domestic Demand & $305,316.30$ & 95.2 & $331,819.17$ & 95.1 & $411,327.78$ & 94.9 \\
\hline
\end{tabular}

timber exported in 1970 and 1975 has been allocated among those regions cited by Kanevskiy and Shaytanov as exporting timber in 1972. The total estimated amount of timber to be exported in 1990 has also been allocated according to the 1972 distribution of Kanevskiy and Shaytanov, although the assumption of no change in the relative importance of regions exporting timber is tenuous.

\section{Methdology and Assumptions}

The objectives of this paper require identification for the years 1970, 1975, 1990 of the regional production of roundwood (and roundwood substitutes) for export, processing, and unprocessed consumption, and of the regional relationship between roundwood (or its equivalent) production and the potential supply of timber.

The first step in the analysis is to determine the volume of production in 87 basic regions of each primary component of the timber and wood-processing industries for 1970 and 1975, and to estimate that expected for 1990; for 
TABLE 2. Regional Surpluses and Deficits of Timber For Domestic Consumption (M⿻3 $\left.(\mathrm{r}) \times 10^{3}\right)$

\begin{tabular}{|c|c|c|c|c|c|c|c|c|c|c|c|c|c|c|c|c|c|c|}
\hline Regions & $\begin{array}{l}1970 \\
\text { Timber } \\
\text { Supply } \\
\end{array}$ & $\begin{array}{l}\% \text { of } \\
\text { Total }\end{array}$ & $\begin{array}{c}1970 \\
\text { Timber } \\
\text { Demand }\end{array}$ & $\begin{array}{l}\% \text { of } \\
\text { Total }\end{array}$ & Surplus & Deficit & $\begin{array}{c}1975 \\
\text { Timber } \\
\text { Supply } \\
\end{array}$ & $\begin{array}{l}\% \text { of } \\
\text { Total }\end{array}$ & $\begin{array}{c}1975 \\
\text { Timber } \\
\text { Demand }\end{array}$ & $\begin{array}{l}\% \text { of } \\
\text { Total }\end{array}$ & Surplus & Deficit & $\begin{array}{l}1990 \\
\text { Timber } \\
\text { Supply }\end{array}$ & $\begin{array}{l}\% \text { of } \\
\text { Total }\end{array}$ & $\begin{array}{c}1990 \\
\text { Timber } \\
\text { Demand } \\
\end{array}$ & $\begin{array}{l}\text { \% of } \\
\text { Total }\end{array}$ & Surplus & Deficit \\
\hline USSR & 305,316 & 100.0 & 305,316 & 100.0 & & & 331,819 & 100.0 & 331,819 & 100.0 & & & 411,328 & 100.0 & 411,328 & 100.0 & & \\
\hline RSFSR & 282,688 & 92.6 & 238,168 & 78.0 & 44,519 & & 309,420 & 93.2 & 262,463 & 79.1 & 46,956 & & 389,386 & 94.7 & 335,375 & 81.5 & 54,011 & \\
\hline $\begin{array}{l}\text { Northwest } \\
\text { European }\end{array}$ & 26,403 & 8.7 & 23,668 & 7.7 & 2,735 & & 26,838 & 8.1 & 25,809 & 7.8 & 1,019 & & 27,956 & 6.8 & 32,230 & 7.8 & & 4,274 \\
\hline North & 59,876 & 19.6 & 27,108 & 8.9 & 32,768 & & 68,903 & 20.8 & 32,407 & 9.7 & 36,497 & & 95,906 & 23.3 & 48,303 & 11.7 & 47,603 & \\
\hline $\begin{array}{l}\text { Centre } \\
\text { Volga-W. }\end{array}$ & 16,172 & 5.3 & 20,349 & 6.6 & & 4,178 & 17,528 & 5.3 & 21,814 & 6.6 & & 4,286 & 21,581 & 5.3 & 26,209 & 6.4 & & 4,629 \\
\hline Urals & 31,692 & 10.4 & 33,854 & 11.1 & & 2,162 & 33,690 & 10.2 & 36,504 & 11.0 & & 2,814 & 39,646 & 9.6 & 44,453 & 10.8 & & 4,807 \\
\hline Black Earth & 2,900 & .9 & 5,846 & 1.9 & & 2,946 & 3,143 & .9 & 5,974 & 1.8 & & 2,831 & 3,874 & .9 & 6,359 & 1.5 & & 2,486 \\
\hline S. Volga & 1,005 & .3 & 11,822 & 3.9 & $\cdots \cdot$ & 10,817 & 996 & .3 & 12,447 & 3.8 & & 11,451 & 967 & .2 & 14,320 & 3.5 & & 13,353 \\
\hline Urals & 54,570 & 17.9 & 35,584 & 11.7 & 18,986 & & 58,352 & 17.6 & 40,688 & 12.2 & 17,664 & & 69,676 & 16.9 & 56,001 & 13.6 & 13,676 & \\
\hline W. Siberia' & 10,700 & 3.5 & 10,096 & 3.3 & 604 & 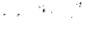 & 11,300 & 3.4 & 10,561 & 3.2 & 739 & & 13,100 & 3.2 & 11,959 & 2.9 & 1,141 & \\
\hline C. Siberia & 57,289 & 18.8 & 42,474 & $13: 9$ & $14 ; 815$ & & 64,590 & 19.5 & 47,986 & 14.5 & 16,605 & & 86,196 & 21.0 & 64,521 & 15.7 & 21,675 & \\
\hline Far East & 14,161 & 4.6 & 14,544 & 4.8 & & 383 & 16,676 & 5.0 & 15,373 & 4.6 & 1,302 & & 25,100 & 6.1 & 17,862 & 4.4 & 7,238 & \\
\hline Siberian North & 2,469 & .8 & 2,156 & .7 & 313 & & 2,242 & .6 & 2,239 & .7 & 3 & & 1,556 & .4 & 2,488 & .6 & & 931 \\
\hline N. Caucasus & 2,605 & .8 & 6,295 & 2.1 & & 3,689 & 2,117 & .6 & 6,185 & 1.9 & $\therefore$ & 4,069 & 617 & .2 & 5,858 & 1.4 & & 5,242 \\
\hline Southwest & 7,825 & 2.6 & 35,140 & 11.5 & & 27,315 & 8,979 & 2.7 & 36,112 & 10.9 & & 27,133 & 12,319 & 3.0 & 39,028 & 9.5 & & 26,709 \\
\hline West* & 15,606 & 5.1 & 21,686 & 7.1 & & 6,080 & 13,990 & 4.2 & 22,716 & 6.8 & & 8,726 & 9,024 & 2.2 & 25,806 & 6.3 & & 16,782 \\
\hline Caucasus & 513 & .2 & 3,099 & 1.0 & & 2,586 & 452 & .1 & 3,062 & .9 & & 2,610 & 269 & .1 & 2,950 & .7 & & 2,681 \\
\hline $\begin{array}{l}\text { Central Asia } \\
\text { SUM of Regional }\end{array}$ & 1,530 & .5 & 11,595 & 3.8 & & 10,065 & 2,033 & .6 & 11,942 & 3.6 & & 9,909 & 3,541 & .8 & 12,981 & 3.2 & & 9,439 \\
\hline $\begin{array}{l}\text { Units } \\
\text { SUM of Regional }\end{array}$ & & & & & 70,221 & 70,221 & & & & & 73,829 & 73,829 & & & & & 91,333 & 91,333 \\
\hline Sub Units & & & & & 94,161 & 94,161 & & & $\cdots$ & & 96,782 & 96,782 & & & & & 115,184 & 115,184 \\
\hline
\end{tabular}

Oblasts,

Krays, and

*The West includes Kaliningrad, Pskov, and Smolensk oblasts of the RSFSR 
discussion, however, the basic regions (oblasts, krays, and ASSR's) are aggregated into larger regional units (described in Barr, 1970) whose composition (Figure 2, Tables 2 and 3) differs from that of the official standard, multi-purpose, large economic regions common to Soviet sources but corresponds to all previous work on Soviet forestry published by the author.

Comparability among sectors of the timber and wood-processing industries is achieved by converting all output figures of processed items into roundwood requirements, $\mathbf{M}^{3}$ (r) (Table 1); when the sectors are combined in this form, they yield regional balances (Table 2) of production and consumption of timber, and surplus or deficit in supply and demand.* The conversion factors employed in this study have been used in previous works by the author (Barr, 1970) and help ensure that total annual supply equals annual demand. Estimation of the regional composition and distribution of the timber and wood-processing industries for 1990, however, not only assumes that conversion factors currently in effect will continue to be relevant, but that the Soviet economy will continue to consume and produce the same commodities in 1990 as in 1975.

Although many economic and social priorities ultimately determine the amount of wood which enters a host of manufactured items extending from lumber to pit props, the demand for timber may, in this paper, be taken as the amount of wood utilized each year in the primary production of wood products and in the preparation of items for final-product use in unprocessed form. Some timber - usually less than five percent of total timber production - is exported as roundwood, and a small amount of wood material is exported in the form of wood chips to Finland and Japan; due to their long-term nature, these activities are assumed to exist through to 1990.

This paper offers a scenario of the 1990 regional composition and distribution of Soviet timber and wood-processing industries (Table 3) based on the assumption that the annual increment of growth in domestic supply and demand for roundwood from 1975 to 1990 will correspond to that recorded for the period, 1970-1975. This scenario envisions for 1990 an aggregate net production (i.e., one that excludes wood chips and mill waste equivalents) of all forms of timber (commercial roundwood, industrial and household fuelwood) of 425.16 million $\mathrm{M}^{3}$ (Table 3), and an aggregate demand for commercial roundwood (and equivalent) and industrial fuelwood of 433.45 million $\mathbf{M}^{3}$ (r) (Table 1).

If the annual increment in growth of demand for commercial roundwood (and equivalent) and industrial fuelwood, 1976-90, however, is assumed to correspond to that recorded in the USSR between 1964 and 1975, then the aggregate demand in 1990 is estimated to be 433.24 million $\mathrm{M}^{3}$. The difference between the two 1990 estimates of demand is less than .05 percent. The 1990 estimate based on the annual increment, 1970-75, is utilized here because

${ }^{*}$ The sources employed to derived Tables 1 and 2 are listed in the appendix. 
TABLE 3. Estimated Net Regional Production of Timber, 1990 (excludes imported roundwood or domestic wood chips or millwaste but includes household fuelwood)

\begin{tabular}{|c|c|c|c|c|c|c|c|c|c|c|c|c|c|c|c|}
\hline \multirow[b]{2}{*}{ Regions } & \multicolumn{2}{|c|}{$\begin{array}{l}(1) \\
\text { Total Commercial } \\
\text { Timber Cut }\end{array}$} & \multicolumn{2}{|c|}{$\begin{array}{l}\text { (2) } \\
\text { Commercial Timber } \\
\text { Cut for Export }\end{array}$} & \multicolumn{2}{|c|}{$\begin{array}{c}\text { (3) } \\
\text { Industrial and } \\
\text { Household } \\
\text { Fuelwood Cut }\end{array}$} & \multicolumn{2}{|c|}{$\begin{array}{c}\text { (4) } \\
\text { Total Annual } \\
\text { Timber Cut } \\
(1)+(3)\end{array}$} & \multicolumn{2}{|c|}{$\begin{array}{l}(5) \\
\text { Forested } \\
\text { Area } \\
(1973)\end{array}$} & \multicolumn{2}{|c|}{$\begin{array}{c}(6) \\
\text { Actual Growing } \\
\text { Stock } \\
(1973)\end{array}$} & \multicolumn{2}{|c|}{$\begin{array}{c}(7) \\
\text { Annual Increment } \\
\text { of Principal } \\
\text { Species }\end{array}$} & \multirow{2}{*}{$\begin{array}{l}\text { Total Annual Timber } \\
\text { Cut as a Percent of } \\
\text { Annual Increment of } \\
\text { Principal Species } \\
\text { (4) as \% of (7) }\end{array}$} \\
\hline & $M^{3} \times 10^{3}$ & $\begin{array}{l}\% \text { of } \\
\text { Total }\end{array}$ & $M^{3} \times 10^{3}$ & $\begin{array}{l}\% \text { of } \\
\text { Total }\end{array}$ & & $\begin{array}{l}\% \text { of } \\
\text { Total }\end{array}$ & $\mathrm{M}^{3} \times 10^{3}$ & $\begin{array}{l}\% \text { of } \\
\text { Total }\end{array}$ & $11 \mathrm{a} . \times 10^{6}$ & $\begin{array}{l}\% \text { of } \\
\text { Total }\end{array}$ & $M^{3} \times 10^{6}$ & $\begin{array}{l}\% \text { of } \\
\text { Total }\end{array}$ & $M^{3} \times 10^{3}$ & $\begin{array}{l}\% \text { of } \\
\text { Total }\end{array}$ & \\
\hline USSR & 355,964 & 100.0 & 22,122 & 100.0 & 69,195 & 100.0 & 425,159 & 100.0 & 769,800 & 100.0 & 81,780 & 100.01 & $, 023,379$ & 100.0 & 42 \\
\hline RSFSR & 337,326 & 94.8 & 21,901 & 99.0 & 66,668 & 96.3 & 403,994 & 95.0 & 728,000 & 94.6 & 78,510 & 96.0 & 940,527 & 91.9 & 43 \\
\hline Northwest & 16,900 & 4.7 & 3,252 & 14.7 & 10,020 & 14.5 & 26,920 & 6.3 & 20,577 & 2.7 & 2,058 & 2.5 & 27,858 & 2.7 & 97 \\
\hline European North & 68,895 & 19.3 & 3,274 & 14.8 & 21,350 & 30.8 & 90,245 & 21.2 & 60,940 & 7.9 & 6,431 & 7.9 & 64,580 & 6.3 & 140 \\
\hline Centre & 22,200 & 6.2 & 619 & 2.8 & 4,800 & 6.9 & 27,000 & 6.4 & 15,385 & 2.0 & 1,721 & 2.1 & 45,077 & 4.4 & 60 \\
\hline Volga-W. Urals & 35,100 & 9.9 & 1,571 & 7.1 & 4,910 & 7.1 & 40,010 & 9.4 & 21,199 & 2.8 & 2,450 & 3.0 & 51,627 & 5.0 & 77 \\
\hline Black Earth & 3,600 & 1.0 & & & 181 & .3 & 3,781 & .9 & 3,488 & .5 & 386 & .5 & 11,232 & 1.1 & 34 \\
\hline S. Volga & 900 & .3 & & & 44 & .1 & 944 & .2 & 2,468 & .3 & 178 & .2 & 6,492 & .6 & 15 \\
\hline Urals & 63,200 & 17.8 & 885 & 4.0 & 9,360 & 13.5 & 72,560 & 17.1 & 73,468 & 9.5 & 8,532 & 10.5 & 98,925 & 9.7 & 73 \\
\hline W. Siberia & 13,100 & 3.7 & & & 2,900 & 4.2 & 16,000 & 3.8 & 33,803 & 4.4 & 4,431 & 5.4 & 55,893 & 5.5 & 29 \\
\hline C. Siberia & 75,100 & 21.1 & 2,212 & 10.0 & 10,448 & 15.1 & 85,548 & 20.1 & 232,617 & 30.2 & 29,213 & 35.7 & 331,015 & 32.4 & 26 \\
\hline Far East & 34,000 & 9.6 & 9,955 & 45.0 & 1,462 & 2.1 & 35,462 & 8.3 & 83,189 & 10.8 & 9,726 & 11.9 & 104,865 & 10.3 & 34 \\
\hline Siberian North & 1,200 & .3 & 133 & .6 & 613 & .9 & 1,813 & .5 & 174,011 & 22.6 & 12,614 & 15.4 & 125,008 & 12.2 & 2 \\
\hline N. Caucasus & 600 & .2 & & & & & 600 & .1 & 3,535 & .5 & 523 & .7 & 9,456 & .9 & 6 \\
\hline Southwest & 9,828 & 2.8 & 44 & .2 & 1,728 & 2.5 & 11,556 & 2.7 & 9,500 & 1.2 & 1,030 & 1.2 & 27,349 & 2.7 & 42 \\
\hline West & 8,457 & 2.3 & 177 & .8 & 580 & .8 & 9,037 & 2.1 & 16,890 & 2.2 & 1,577 & 1.9 & 38,800 & 3.8 & 23 \\
\hline Caucasus & 269 & .1 & & & 40 & .1 & 309 & .1 & 4,130 & .5 & 550 & .7 & 7,361 & .7 & 4 \\
\hline Central Asia & 2,615 & .7 & & & 759 & 1.1 & 3,374 & .8 & 14,600 & 1.9 & 360 & .4 & 17,841 & 1.7 & 19 \\
\hline
\end{tabular}

The West includes Kaliningrad, Pskov, and Smolensk oblasts of the RSFSR.

'Includes forests of all forestry and non-forestry ministries and administrations.

Sources: The data in this table are derived from the sources listed in the Appendix for Tables 1 and 2. 
some of the sectoral changes within the forest industry in this period appear more likely than changes from 1964-75 to extend into the near future.

The period 1970-75, for example, saw impressive increases in production of fiberboard and particleboard as replacements for lumber and plywood, and in consumption of mil residues and industrial fuelwood as substitutes for commercial roundwood in wood-processing. This period was associated with relatively small increases in the output of lumber, plywood, and wood pulp. Consequently, although the 1990 national aggregate demand by the timber and wood-processing industries can be estimated accurately on the basis of national change in each sector for either 1964-75 or 1970-75, different relative emphasis on the component sectors of the timber and wood-processing industries in each period affects the level of demand expected for each region in 1990. Those regions displaying the greatest increment 1970-75 feature most prominently in the estimates of regional change, 1975-90. Estimation of 1990 on the basis of the period 1964-75 instead of 1970-75, therefore, would have included major past changes in industries which are now receiving (Holowacz, 1977) low investment priority.

DISCUSSION: THE SPATIAL CONCURRENCE OF TIMBER SUPPLY AND DEMAND, 1990

\section{Regional Levels of Timber Harvest and Growth}

Estimates of the 1990 total timber harvest (Table 3) reveal that the European North, Urals, Central Siberia, and Far East will account for two-thirds of the total. If the relatively small contributions of the Northwest and Western Siberia are added to this share, then nearly 78 percent of Soviet timber in 1990 will originate from these six regions, which in 1973 accounted for 74 percent of the Actual Growing Stock and 67 percent of the annual increment of principal forest species. The estimates of timber harvest for 1990 thus indicate that an approximate balance between the relative location of timber harvest and that of timber reserve will prevail by that date although the annual increment in the six regions - 685 million $\mathrm{M}^{3}$ - will more than support their expected timber harvest of 347 million $\mathrm{M}^{3}$. If only 56 percent the share of all commercial forest currently accessible - of the annual increment of these six regions is assumed to be available for harvesting in accessible stands, then the 384 million $\mathrm{M}^{3}$ which can be cut in these regions is 37 million $\mathbf{M}^{3}$ in excess of that predicted for 1990 . Thus, without drawing extensively on the forests of the Siberian North - Yakutia, Magadan, and Kamchatka - the Soviet Union will be able to meet its incremental needs for timber by 1990 from the major accessible forests of the Taiga extending from the White Sea to the Sea of Okhotsk.

The remaining regions - excluding the Siberian North which is unlikely to become a significant timber harvesting region by 1990 - account for approximately 22 percent of the expected 1990 timber harvest and approximately 21 percent of the annual increment of principal forest species. If the forests of the remaining regions are assumed (based on their proximity to railway and river transportation arteries) to be 80 percent accessible, then 
they could supply 172 million $\mathrm{M}^{3}$ which is 74 million $\mathrm{M}^{3}$ in excess of their expected harvest of approximately 98 million $\mathrm{M}^{3}$. These regions also possess sufficient average-age, mature, and overmature timber to support their expected 1990 levels of cutting.

While the data presented in this paper support the contention that the Soviet Union has sufficient reserves of timber to meet expected levels of demand in 1990 and possibly for several decades beyond that date, they do not reveal whether the USSR can meet future demand for individual species of timber without making significant changes in the species allocated to wood processors. This problem requires extensive further investigation of the literature for clues as to the relative current importance of each species in the timber harvest of major forest regions, and the importance which demand for each species is likely to assume in the future. If Soviet foresters are able to substitute greater amounts of larch and deciduous species, for example, in the domestic consumption of pine, spruce, fir, and Siberian Stone Pine, then their ability to continue to supply these four species at least to foreign consumers is assured. Nevertheless, this issue requires investigation and evaluation of related technological, economic, and market forces excluded from the present analysis.

\section{Export Impact on World Markets}

Estimates in Table 1 suggest that the USSR may export approximately 22 million $\mathrm{M}^{3}$ of roundwood by 1990 if world markets continue to be satisfied by the USSR as they have been in the 1970s. Soviet exports to Japan, Finland and the CMEA countries are subject to long-term agreements and mitigate sudden changes caused by market fluctuations, although poor business conditions in Japan have recently caused cutback in the amount of roundwood and mill residues being shipped by the USSR to that country. World Wood (1976) has reported that "reduction in the production of pulp and paper in Japan has induced the Japan Chip Trading Co., which is the sole importer of Siberian Chips for pulp and paper manufacturers, to ask the Soviet Lumber Export Corporation to cut down its delivery of chips to $450,000 \mathrm{M}^{3}$. This is 60 percent less than stipulated in their ten-year contract. American suppliers have been asked to make a similar reduction." If Sutton's prediction $(1975, \mathrm{p}$. 136) is accepted, that timber deficits in the USA by the end of the century probably can be satisfied by surplus production shipped from Canada, then the major market area of uncertain but potentially great impact for Soviet timber sales must be the markets of western Europe - where imports from Sweden and Finland may be negligible by the end of the century (Sutton, 1975 , p. 136) - and Japan. Nearly 66 percent of the USSR's volume in roundwood equivalent units of principal forest-product exports in 1974 was directed to the countries of Europe (eastern and western Europe); 21 percent went to Japan, and 13 percent to other nations (United Nations, 1976, p. 148). Exports of all forest products from the USSR by the year 2000 are expected to make up 11-12 percent of the total volume of industrial roundwood removals 
in that country and reach 55-65 million $\mathrm{M}^{3}(\mathrm{r})$, of which Europe may receive 30 to 35 million $\mathrm{M}^{3}$ (r) (United Nations, 1976, p. 148).

Soviet exports of timber have been estimated in the present study to be approximately 5 percent of domestic industrial timber supply by 1990; if the estimate of 65 million $\mathrm{M}^{3}$ (r) of forest-product exports is accepted for 1990 , then approximately 27 million $\mathrm{M}^{3}$ of roundwood could be exported to all markets; acceptance of a total export volume of 55 million $\mathbf{M}^{3}$ (r), also representing 12 percent of industrial roundwood removals, and an export of timber comprising 5 percent of industrial roundwood removals, leads to a total timber export of 23 million $\mathbf{M}^{3}$ in 1990 . This lower estimate of 23 million $\mathbf{M}^{3}$ is close to the figure of 22 million $\mathrm{M}^{3}$ estimated in the present study. If expectations that European nations will be able to obtain only 55 percent of total Soviet forest product exports by the year 2000 are applied to Soviet timber exports, then Europe could receive between 12.6 and 14.8 million $\mathrm{M}^{3}$ of Soviet timber. These shipments could be achieved as early as 1990 and still conform to the general timber export volume estimated for that year in this study.

Given that the U.N. estimates pertain to the year 2000, then the estimate in this study confirms that European timber demand can be adequately satisfied by Soviet supply in 1990, and probably for many years following 1990, in view of the large reserves which the USSR appears to have when its forest resource is analyzed in terms of the expected balance between regional supply and demand.

If Europe's demand for Soviet timber were to expand more quickly than anticipated in the U.N. study, then the expanded demand in 1990 could still be easily met from Soviet timber reserves. If growth of European demand were to contract by 1990 , then the Soviet Union might engage in excessively aggressive marketing tactics to ensure as much access as possible to European markets. The U.N. study noted that "it is difficult to find a rational basis on which to estimate future exports of forest products from North America" (United Nations, 1976, p. 159); it is difficult for any individual researcher, therefore, to predict the impact of Soviet timber on world or European markets in 1990 if these markets should be depressed and encourage excessively aggressive competition from their traditional timber suppliers. If the relative magnitude of Soviet timber exports should be smaller to Europe but greater to Japan in 1990 than in 1974, then North American sales by 1990-2000 should increase slightly in Europe to pick up the shortfall in Soviet sales, and should also increase in Japan as that country expands its total need for timber imports but is unable to account for its entire increment of demand from the USSR (United Nations, 1976, pp. 161, 163).

If the USSR's real ability to export timber by 1990 is that estimated in this study, and if world demand - particularly that of Europe, Japan and North America - continues in the manner predicted by the U.N., then Soviet timber production is unlikely to be capable of dominating world markets by the last decade of this century. The likely significance of Soviet timber sales abroad by 1990 is that they will be insufficient to satisfy the potential world 
demand for Soviet timber and will, therefore, enable other timber-exporting nations such as Canada to sell timber on those world markets.

\section{Problems and Options in Comprehensive Development of \\ Northern and Eastern Forests}

When Soviet exploitable forests are compared with the commercial timberlands of the USA and the Canadian forest suitable for regular harvest, the area and maximum allowable cut of the North American forests are respectively 1.36 and 1.47 times greater than those of the USSR, although the total volume of the Soviet forest exceeds that of North America by approximately one-third (Sutton, 1975, p. 113). The most realistic estimate of Soviet annual allowable cut accepted by Sutton is almost identical to that of the United States.

Unlike those of either the United States or Canada, however, the Soviet Union's forests do not lie adjacent to established or relatively accessible areas of the country. The basic problem of the geography of Soviet forests is that most incremental supply of roundwood in the near and intermediate-term future will have to originate in forests which are relatively inaccessible to existing interregional transportation facilities and to existing wood-processing centers. Furthermore, these geographically peripheral forests are heavily dominated by stands of larch. In some of the peripheral forests, such as in those of the European North and Western Siberia, the river systems facilitate rafting of logs, but traditional forms of water-borne movement of logs now strongly conflict with the interests of many other groups, particularly of the fishing and conservation lobbies. The use of rivers to float logs in Siberia could theoretically obviate the need to invest in rail facilities, except that increased use of Siberian forests will probably necessitate large movements of larch, a species which has a high propensity to sink.

In many of the remote forest stands, timber floating is the only way to move timber to market. At the present time, approximately 50 percent of all timber felled moves at least some distance by water, but in the North, Siberia and the Far East, this figure exceeds 70 percent. Soviet waterways suitable for timber floating are $140,000 \mathrm{~km}$ in length and support a timber throughput of 53 billion ton-kilometers per annum (Lesnaya Promyshlennost' 1977b).

The geographical distribution of timber reserves in the USSR thus does not coincide with the basic rail transportation system and is heavily characterized by a North/East-West/South dichotomy. The North and East of the USSR have most of the forest reserves but are dominated by inhospitable terrain, difficult physical environments for logging and living, harsh climates and slow natural growth rates, and relative inaccessibility to the USSR's domestic and Eastern European markets. The West and South, on the other hand, have environments conducive to human and plant communities, terrain that does not usually offer difficulties to forest-related equipment, relatively mild climates and fast growth rates, and are either synonymous with, or relatively accessible to, the major industrial consumers of roundwood in the USSR and Eastern Europe (the CMEA Countries). All regions, however, are relatively 
far from world demand for roundwood although some of the river- and port-oriented processing facilities of the North and East are economically accessible to European and Asian markets.

The basic dilemma caused by the spatial dichotomy of resource distribution in the USSR for Soviet foresters is compounded by the large amounts of mature and overmature timber in the North and East and by the extensive overcutting of forests in the West and South. Although the West and South offer the greatest potential for regeneration of forests, they also have the greatest demands for agricultural land and for land related to urban and industrial growth. Furthermore, regeneration is expensive even when the supporting infrastructure is in place. In the North and East, however, the forests are old and can be cut greatly in excess of their current mean annual increment with consequent savings to the forest economy, although the relative absence of railways, settlements, and processing facilities means that development of forests in these regions places heavy demands on the investment capital of the USSR. Competing demand for capital is one of the reasons for the relatively slow development which northern and eastern forests have hitherto experienced.

The impact of the long-standing relative dearth of capital for development of northern and eastern forests has been compounded in the 1970s by the growing shortage of labor in these regions. Insufficient labor in the peripheral northern and eastern regions of the USSR thwarted plans for the development of manufacturing away from the heartland of the USSR as early as the late 1950s but its impact on the ability of Soviet leaders to develop natural resource sites has only bey apparent in the 1970s; areas synonymous with greatest potential are also those with the most severe labor problems. Although labor is relatively more available in the West and South, the demands by other industrial sectors, including agriculture, mean that labor for use in the forests and wood-processing mills of the heartland is also in short supply. In all regions, therefore, the shortage of labor is becoming more severe and requires attendant investments in capital equipment to increase productivity in the forests as well as capital investment in wood-processing.

Shortage of capital and labor are probably major factors leading the USSR to modernize many processing facilities in established centers of the West and South rather than to proceed as rapidly as possible with the creation of extensive new processing centers in the North and East. Shortages of labor in the North and East have not only influenced the growth of primary manufacturing facilities but have necessitated the import of labor from Bulgaria (Lesnaya Promyshlennost', 1977d) for the past ten years to harvest timber in the Komi ASSR; in the current Five Year Plan, 1976-80, this activity of the Bulgarians in Komi is to be matched by expansion of participation of North Korean labor in the logging industry of Khabarovsk territory and Amur oblast (Lesnaya Promyshlennost', 1977c). Shortage of capital has led the USSR to engage members of CMEA in joint manufacturing and processing ventures such as the Ust'-Ilimsk wood-processing complex in which five East European nations are participating with the USSR. The Soviet Union will 
carry out engineering preparation of the site and design and construct the pulp mill. Approximately 40 percent of the project's cost is being met by Bulgaria, Hungary, East Germany, Poland and Rumania in the form of machinery, equipment, materials and transportation and communication systems (CDSP, 1976a).

Soviet planners and leaders obviously realize that, whatever their decisions concerning the amount of timber to be harvested, and the type of processing to be conducted, activities in the North and East will increasingly involve foreign participation in the form of labor (CDSP, 1977d), capital, or both. Suggestion that the USSR may eventually become the destination of numerous "Guest Workers" in a manner similar to Western Europe in the 1960s may be premature, but the increasing attraction to CMEA, for example, of Mediterranean and other Third World Nations may result in large-scale temporary enlistment of foreign labor to develop the timber and wood-processing industries of the North and the East by 1990 (Smith, 1977).

The relative difficulty of developing the infrastructure of peripheral regions is evident from reports on construction of the "project of the century," the BAM (CDSP 1976b, 1976c, 1976d, 1977a). The BAM is placing inordinate demands on the USSR's labor and capital supply, and the traumas associated with the climate and living conditions throughout the BAM territory attest to the great difficulties of human habitation in the peripheral Soviet regions (Alan Smith (1976, p. 481) refers to their geography and climate as "A Deterrent to Overpopulation'). Furthermore, the BAM itself is dependent in many respects on foreign technology and equipment, and its very economic viability may be a function of the USSR's ability to export raw materials to countries of the Pacific Basin. The BAM initially will facilitate the export of raw materials and throughout the rest of the 20 th century probably will be heavily associated with movement of petroleum, timber and minerals for export. There is no indication to date that large shares of the total capital slated for investment in wood-processing in the near future, for example, will be marshalled into projects associated with the BAM (CDSP, 1976c) and other Siberian railways. In fact, if economic viability of the BAM were predicated on the generation of flows of high-value manufactured or semi-manufactured commodities such as lumber, pulp, and paper, then a significant share of capital being invested in the timber and wood-processing industries during the Tenth Five Year Plan, 1976-80, should be associated with projects located in the areas served by the BAM. Such an investment pattern is not occurring, however, and the current location of Soviet wood-processing investment would likely to be no different if the BAM had never been conceived.

Further evidence that Soviet planners and leaders lean heavily toward development of the timber and wood-processing industries in established regions of the West and South is found in the current shifts toward greater use of wood waste and industrial fuelwood as substitutes for commercial roundwood. Mill waste is rapidly becoming the most significant ingredient in the production of wood pulp and particleboard, and is synonymous with a more comprehensive use of wood fiber in established timber-producing areas. 
Fuller use of roundwood delays the need to obtain substantial increments of fiber from northern and eastern forests. Similarly, the substitution of industrial fuelwood for distant supplies of commercial roundwood is increasing in the processing industry, and reduces the need for relocation of both investment and labor in peripheral regions (CDSP, 1977b and 1977c; Kudryavtsev, 1972; Lesnaya Promyshlennost', 1977a, 1977b, and 1977c). All these substitutes for commercial roundwood appear to be significantly retarding the extent to which Soviet timber and wood-processing industries need to relocate in the North and East by 1900 .

The regional location of the Soviet timber and wood-processing industries implies at first glance the existence of opposing "forces pushing development of the Soviet forest products industry in opposite directions" (North and Solecki, 1977, p. 301). The tendency for development of certain types of capital-intensive wood-processing in the North and East, and the continued growth of a broad spectrum of development in the West and South, however, should not be taken as conclusive evidence of a conflict in development of timber and wood-processing industries but rather as complementary aspects of a general process of improvement in the spatial economy of the entire Soviet forest industry. This industry is complex and many of its subdivisions possess characteristics which differ from each other. Soviet planning directives increasingly recognize the need to develop capital-intensive projects for the manufacture of lumber, pulp, paperboard, and fiberboard in peripheral regions while facilities for the manufacture of paper, particleboard, plywood, etc. are expanded in the heartland. Soviet reluctance to abandon regeneration activity and to forego new investment in existing European facilities in favor of a wholesale movement to the North and East suggests that the latter regions will undergo development only to the extent that investment in the West and South cannot be carried out more profitably.

The nature of wood-processing itself, however, suggests that the primary forms of wood conversion involving significant loss of weight will continue to be raw material oriented irrespective of the general locational forces being exerted on the spatial economy, and will continue being located in the North and East; secondary forms of conversion such as paper and fiberboard may be expanded near the western Soviet borders (for sales to CMEA and western European markets) on the basis of in-transit processing of northern and eastern semi-manıfactured inputs, or near many of the existing wood-processing facilities and markets located in the major domestic European regions of the USSR.

Except for the upgrading of processing and related transport facilities in the small number of port complexes in the North and East, the pattern of development of Soviet timber and wood-processing industries evident today probably would not be different from that associated with a Soviet economy lacking a strong commitment to international trade. Forests of the European North, northern Urals, central Siberia and the Far East might not have undergone such significant development during the past six decades if the USSR did not ship timber abroad, but the pattern of wood-processing 
(excluding facilities located at Archangel and Igarka) which has developed during this period has chiefly been intended to satisfy domestic markets. Clearly, therefore, Soviet leaders have traditionally possessed options on the extent to which they are prepared to develop timber and wood-processing industries related to foreign trade. The option to export timber has been exercised for many reasons including the need to earn foreign exchange as quickly as possible. In the future, however, the ability to earn foreign exchange without substantial investments of capital, or capital substitutes such as foreign labor rather than conscripted labor, will be much less than in the past. Furthermore, that timber which can be harvested with available labor faces many competing demands within the domestic economy. Thus, on the one hand, shortages of capital and labor may force curtailment of significant exports of raw timber. On the other hand, however, export of timber currently constitutes the greater source of foreign exchange from the Industrial West after the export of petroleum.

A major dilemma thus facing those Soviet leaders responsible for timber and wood-processing, foreign trade, and general economic and industrial growth is that future growth of the Soviet industrial economy appears to be predicated on the import of western technology, and that the ability to pay for such technology rests to a significant degree on earnings from the Cinderella of Soviet industry, the forestry sector. Futhermore, sustained output and future growth of the timber and wood-processing industries cannot be achieved without these industries having extensive access to western technology, i.e., to foreign exchange funds. Soviet leaders do not appear to have any option but to develop the timber industry in the future, and to continue to export timber and to effect the necessary related changes in the geography of timber production. The scenario developed in this paper seems quite justified in assuming that the USSR will continue to develop its timber-export sector as in the past and will produce such timber from the traditional northern and eastern regions.

Developments in the 1970s suggest, however, that this expectation of export based on timber rather than on wood products may be somewhat circumvented by greater integration within CMEA whereby the Soviet Union will supply forest products in exchange for CMEA-developed or CMEA-purchased high-technology goods. Soviet leaders show increasing signs of a shift toward reliance on CMEA as a source of the items which convertible currency might purchase on world markets. If CMEA projects become more numerous in the USSR, and if these projects involve expansion of wood-processing either in the USSR or on the basis of USSR timber in the CMEA countries themselves, then Soviet timber supplies now exported to the Industrial West may increasingly become directed toward CMEA or toward CMEA-related projects within the Soviet Union. Whichever variant involving CMEA is adopted, however, the geography of timber and primary wood-processing industries associated with CMEA integration is unlikely to be substantially different from that inherent in current developments related to satisfying domestic Soviet demand. 
Traditional export has been water-borne from the lumber and timber ports of the North and East. CMEA trade is likely to involve rail shipments from accessible Soviet regions to eastern Europe. Wood-processing, never a major contributor to forest-based exports to the Industrial West, would likely occur in those areas accessible to the Soviet rail network such as Ust'-Ilimsk rather than at ports or in the forest-deficit regions of the West and South although the location of secondary processing facilities on the western border of the USSR would ensure that country of the retention of political control over investment while maintaining direct access to the CMEA markets.

Closer integration within CMEA is unlikely to affect the geography of Soviet wood-processing or to reduce the need of the USSR to produce timber or timber-related goods for many domestic and other international markets. Satisfaction of all these markets throughout the remaining decades of the twentieth century, however, will necessitate significant expansion of timber harvesting in the North and East but will also induce greater locational economies in wood-processing and resource management in the forests of the West and South.

\section{CONCLUSIONS}

Analysis was conducted on the basis of forest-product data expressed in terms of roundwood equivalent, and on the expectation that the Soviet Union will engage in a level of timber harvesting and consumption in 1990 consistent with growth of its forest economy between 1970 and 1975. The estimates of timber available for export in 1990 concur with those of the U.N. for the year 2000 , although the level of timber to be harvested and consumed in the USSR in 1990 estimated in this study is lower than that presented in all other western estimates of future Soviet forest activity. No other western study, however, has estimated future timber supply and demand by examining the likely regional structure of the timber and wood-processing industries, or by measuring the critical increases in timber harvesting which can be realistically posited and achieved in the European North, in Western and Eastern Siberia, and in the Far East.

The scenario presented for 1990 thus portrays the characteristics of the timber and wood-processing industries to be expected by 1990 if the USSR continues to change and grow in a manner consistent with most of its post-World War II development. Most other expectations of future performance in the forest industries assume that the USSR will radically depart from past growth patterns, whereas Soviet experience and general behavior are shown in this paper to demonstrate that the country will record significant achievements if it is able to expand and develop in a manner consistent with that of the recent past.

\section{ACKNOWLEDGEMENTS}

The author gratefully acknowledges the support provided for this research by the directors of the Association of American Geographers Project on Soviet Natural Resources in the World Economy, and the helpful suggestions offered by the referees of Arctic. 


\section{REFERENCES}

BARR. B. M. 1966. The Importance of Regions in Analyses of the Soviet Forest Resource: A Reply. The Canadian Geographer, 10(4): 234-37.

1970. The Soviet Wood-Processing Industry: A Linear Programming Analysis of the Role of

Transportation Costs in Location and Flow Patterns. University of Toronto Press, Toronto, 135 pp.

1971. Regional Variation in Soviet Pulp and Paper Production. Annals, Association of American Geographers, 61: 45-64.

and K. SMILLIE. 1972. Some Spatial Interpretations of Alternative Optimal and Suboptimal

Solutions to the Transportation Problem. The Canadian Geographer, 16(4): 356-64.

1978. Domestic and International Implications of Regional Change in the Soviet Timber and Wood-Processing Industries, 1970-1990. Association of American Geographers Project on Soviet Natural Resources in the World Economy, Discussion Paper No. 4, Washington, D.C., $92 \mathrm{pp}$.

CDSP(Current Digest of the Soviet Press). 1976a. 28(11): 27.

1976b. 28(14): 21,32 .

1976c. 28(19): $1-6,27$

1976d. 28(36): 9-11.

1976e. 28(48): 14, 18.

1977a. 29(28): 3-6, 8 .

1977b. 29(47): $1-4$.

1977c. 29(51): 7, 28.

1977d. 29(52): 20.

HOLOWACZ, J. 1977. World Wood Review, 18(6): 20.

KANEVSKIY, M. V., AND G. YA. SHAYTANOV. 1975. Lesnoy Eksport SSR. Lesnaya Promyshlennost', Moscow, 109-120.

LESNAYA PROMYSHLENNOST'. 1977a. (1): 1-3.

- 1977b. (8): 6-7.

1977c. (10): 1-3.

1977d. (11): 3-8.

KUDRYAVTSEV, YU. A. 1972. Lesnaya Industriya Strany Sovetov. Lesnoy Zhurnal, (6): 11-17.

NARODNOYE KHOZYAYSTVO RSFSR za 60 LET. Statisticheskiy Ezhegodnik. 1977. Statistika, Moscow, $367 \mathrm{pp}$.

NARODNOYE KHOZYAYSTVO ssSR za 60 LET. Yubileyniy Statisticheskiy Ezhegodnik. 1977. Statistika, Moscow, 710 pp.

NORTH, R. N., AND J. J. SOLECKI. 1977. The Soviet Forest Products Industry: Its Present and Potential Exports. Canadian Slavonic Papers, 19(3): 281-311.

SHABAD, T. 1977a. Private communication to the author. Washington, D.C., October.

1977b. Status of the 15-year Plan (1976-1990). Soviet Geography: Review and Translation, 17(9): 699-700.

SMITH, A. B. 1976. Soviet Dependence on Siberian Resource Development. Soviet Economy in a New Perspective, Joint Economic Committee, Congress of the United States, U.S. Government Printing Office, Washington, 479-499.

SMITH, A. J. 1977. The Council of Mutual Economic Assistance in 1977: New Economic Power, New Political Perspectives and Some Old and New Problems. East European Economies Post-Helsinki, Joint Economic Committee, Congress of the United States, U.S. Government Printing Office, Washington, 152-73.

SUTTON. W.R.J. 1975. The Forest Resources of the USSR: Their Exploitation and Their Potential. Commonwealth Foresty Review, (160): 110-38.

UNITED NATIONS, ECONOMIC COMMISSION FOR EUROPE AND FAO. 1976. European Timber Trends and Prospects 1950-2000. Supplement 3 to Vol. 29 of the Timber Bulletin for Europe, Geneva.

WORLD WOOD. 1976. 17(11): 5 . 


\section{Appendix: Sources for Tables 1 and 2}

Table 1:

The basic sources of statistical material for 1970 and 1975 are: Narodnoye Khozyaystvo SSSR $v$ 1970 godu (Moscow, 1971), Narodnoye Khozyaystvo SSSR v 1975 godu (Moscow, 1976), Narodnoye Khozyaystvo RSFSR v 1970 godu (Moscow, 1971), Narodnoye Khozyaystvo RSFSR v. 1975 godu (Moscow, 1976). Vneshnyaya Torgovlya SSSR za 1970 godu (Moscow: 1971), and Vneshnyaya Torgovlya SSSR v 1975 godu (Moscow: 1976).

Supporting sources and those containing fragmentary and fugitive data are I. S. Yarmola, Voprosy Lesosnabzheniya v. SSSR, 2nd ed. (Moscow: Lesnaya Promyshlennost', 1972); M. V. Kanevskiy and G. Ya. Shaytanov, Lesnoy Eksport SSSR (Moscow: Lesnaya Promyshlennost', 1975); Narodnoye Khozyaystvo Belorusskoy SSR, 1976 (Minsk, 1976); Spravochnik Ekonomista Derevoobrabatyvayushchey Promyshlennosti, 2nd ed. (Moscow: Lesnaya Promyshlennost', 1974); Ekonomika i Kul'tura Litovskoy SSR v 1975 godu (Vil'nyus: 1976); Narodnoye Khozyaystvo Latviyskoy SSR v 1973 godu (Riga: 1974); N. A. Medvedev, Ekonomika Lesnoy Promyshlennosti, 2nd ed. (Moscow: 1976); Z. V. Uchastkina et al., Spravochnik po Ekonomike dlya Rabotnikov Tsellyulozno-bumazhnykh Predpriyatiy (Moscow: Lesnaya Promyshlennost', 1973); Z. V. Uchastkina, Ekonomike Tsellyulozno-bumazhnoy Promyshlennosti, 2nd ed. (Moscow: Lesnaya Promyshlennost', 1973); V. V. Glotov, Lesnaya i Lesopererabatyvayushchaya Promyshlennost' Ekonomicheskikh Rayonov (Moscow: Lesnaya Promyshlennost', 1970); Narodnye Gospodarstvo Ukrayns'koy RSR u 1973 rotsy (Kiev: 1974); G. K. Stupnev, S. M. Khasdan, and V. N. Plakhov, Derevoobrabatyvayushchaya Promyshlennost' za Gody Devyatoy Pyatiletki (Moscow: Lesnaya Promyshlennost', 1976); S. M. Khasdan, Sostoyaniye $i$ Osnovnye Napravleniya Razvitiya Derevoobrabatyvayushchikh Proizvodstv (Moscow: Lesnaya Promyshlennost', 1973); Ekonomika $i$ Kul'tura Litovskoy SSR v. 1974 g. (Vil'nyus, 1975); Narodnoye Khozyaystvo Estonskoy SSR v. $1976 \mathrm{~g}$. (Tallin, 1970).

The method used to calculate figures for 1990 is discussed in Barr, 1978, pp. 14-22. Calculation of the 1990 values of Imported Roundwood and Roundwood Export, however, departs slightly from that used for the other categories in order to avoid the methodological problem of negative imports which would occur if the negative change, 1970-75, in Imported Roundwood were projected to 1990 .

Household fuelwood does not comprise part of inter-regional shipment of roundwood and is excluded from Table 1; household fuelwood is included in Table 3, however, to gauge the effect of all timber harvesting on the annual increment of principal species.

The terms employed by foresters to describe the USSR's forests are discussed in Barr (1970, pp. 40-44) and Sutton (1975, pp. 110-112).

Conversion factors relating units of production of each wood product to its roundwood equivalent are discussed in B. M. Barr, The Soviet Wood-Processing Industry: A Linear Programming Analysis of the Role of Transportation Costs in Location and Flow Patterns (Toronto: University of Toronto Press, 1970), pp. 22-26.

Table 2:

In addition to the sources for Table 1, Table 2 was compiled from data in V. A. Nikolyuk, "Izmeneniya v Lesnom Fonde v Rezul'tate Khozyaystvennoy Deyatel'nosti," Lesnoye Khozyaystvo, 1975, No. 7, pp. 2-6; S. G. Sinitsyn, Lesnoy Fond i Organizatsiya Ispol'zovaniya Lesnykh Resursov SSR (Moscow: Lesnaya Promyshlennost', 1976); Personal communications, Mr. J. H. Holowacz, Ontario Ministry of Natural Resources; Narodnoye Khozyaystvo SSSR v $1973 \mathrm{~g}$. (Moscow: 1974); Narodnoye Khozyaystvo RSFSR v 1973 g. (Moscow: 1974). 